\title{
Calcareous soils in the Northeastern of Brazil: Alterations of attributes from different land use history
}

\author{
João Bosco Vasconcellos Gomes ${ }^{\mathrm{a}, *}$, Marcelo Ferreira Fernandes ${ }^{\mathrm{b}}$, Edson Patto Pacheco ${ }^{\mathrm{b}}$, \\ Antônio Carlos Barreto ${ }^{\mathrm{b}}$, Lloyd Darrell Norton ${ }^{\mathrm{c}}$, Nilton Curi ${ }^{\mathrm{d}}$ \\ a Empresa Brasileira de Pesquisa Agropecuária, Embrapa Florestas, PBX 319, CEP 83411-000 Colombo, PR, Brazil

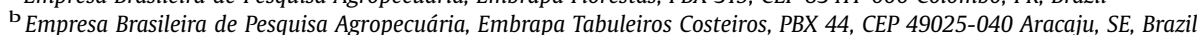 \\ ${ }^{\mathrm{c}}$ Department of Agronomy, Purdue University, West Lafayette, IN, USA \\ d Universidade Federal de Lavras, Departamento de Ciência do Solo, PBX 3037, CEP 37200-000 Lavras, MG, Brazil
}

A R T I C L E I N F O

Article history:

Received 5 January 2015

Received in revised form 30 June 2015

Accepted 9 July 2015

Keywords:

Chernosols

Soil quality

Dry forest

\begin{abstract}
A B S T R A C T
The intensive machinery traffic is an important feature of industrial agroecosystems. This traffic when performed under inappropriate moisture conditions can accelerate a series of soil physical properties exchanges, causing deterioration of several soil quality indicators. Intensive agricultural activity is advancing rapidly in western Sergipe State and northeastern Bahia State (Brazilian semi-arid regions), mainly on soils developed from limestone substrata. This study characterized the soils and investigated the effect of increasing periods of corn crops and other land use types on soil attributes of calcareous soils from Western Sergipe State, with emphasis on physical attributes, particulate organic matter, and total organic C. Five combinations with five replicates of land use were selected: dry forest (DF); corn crop (first, fourth and tenth year - C1, C4 and C10) after forest removal; and intensive pasture (IP). The study areas were dominated by soils with vertic properties. Almost all the chemical and physical attributes showed a lesser quality in IP sites compared with the other treatments. The differences among the DF sites and corn crop sites were smaller. When compared the land use time of corn crop treatments (with DF as zero time), tenuously, some attributes formed two groups, where DF and C1 treatments were separated from C4 and C10 treatments. Regarding the comparison of all treatments, the non-metric multidimensional scaling technique explained 94\% of the variability (in two axis) of the 19 attributes analyzed, being the major part represented by axis 1 (79\%). The IP sites had the greatest soil physical degradation index among all groups. The $\mathrm{C} 1$ sites had significant contrast compared with the DF sites. The C4 sites showed a loss of quality in many soil physical properties compared with $\mathrm{C} 1 \mathrm{sites}$. There were no differences between the C4 and C10 sites. This shows that in order to achieve a near steady state a greater number of cultivation years is required.
\end{abstract}

(c) 2015 Elsevier B.V. All rights reserved.

\section{Introduction}

The intensive machinery traffic is an important feature of industrial agroecosystems. This traffic when performed under inappropriate moisture conditions can accelerate a series of soil physical properties exchanges (Hamza and Anderson, 2005; Severiano et al., 2008; Sant'anna et al., 2009), causing deterioration of several soil quality indicators. The most classical result of these changes is the appearance of compacted layers in the root growth influence zone (Ng Cheong et al., 2009), that very commonly cause

\footnotetext{
* Corresponding author at: Embrapa Florestas, PBX 319, CEP 83411-000 Colombo, PR, Brazil.

E-mail address: joao.bv.gomes@embrapa.br (J.B.V. Gomes).
}

decreasing agronomic productivity over time (Bronick and Lal, 2005).

Intensive agricultural activity is advancing rapidly in semi-arid landscapes in western Sergipe State and northeastern Bahia State, mainly on soils developed from limestone substrata, which dominate an approximate area of $878 \mathrm{~km}^{2}$ (Embrapa, 1975, 1977). For Sergipe state, with $21,994 \mathrm{~km}^{2}$ of total area, they represent a significant area of land (approximately $328 \mathrm{~km}^{2}$ or $1.5 \%$ of the state's area). Undoubtedly, these soils represent the best land in the state for annual row crop cultivation. In these areas, the traditional use was pasture, with the crop area showing modest numbers. With the development of a hybrid maize and varieties validated to work in this region, the last two decades have resulted in a great increase in maize planted area. Besides the availability of appropriate genetic materials, a combination of climate and, 
especially, favorable soil has allowed for corn yields (up to $10 \mathrm{tha}^{-1}$ ) never achieved before in that region. These fields have yields comparable with traditional productive regions of this crop in Brazil [such as Paraná State, with 845.219 ha harvested with an average yield of $8160 \mathrm{~kg} \mathrm{ha}^{-1}$ (Shioga et al., 2013), compared with an approximate average yield of $4000 \mathrm{~kg} \mathrm{ha}^{-1}$ for Brazil].

Maize is mainly cultivated in the region with conventional tillage, involving plowing and harrowing. The machinery traffic continues in various mechanized activities (application of herbicides, fertilizers, pesticides and harvesting). Some no-tillage initiatives were started with adaptations due to the large water deficit in the region.

The impact of intensive management on soil quality, has been quantified using different indicators. The physical qualities are mainly associated with a dry soil consistence and the transmission of gases and liquids in the root zone of crops, whereas, these characteristics are greatly influenced by other attributes (physical, mineralogical, chemical and biological), by management practices, and local geomorphology and climate (Reynolds et al., 2007). Some attributes are highly valued in soil quality differentiation, especially organic $C$ being recognized as the attribute with greater discriminating power (Shukla et al., 2006), followed by various physical attributes such as bulk density, permeability, various forms of porosity, water retention and aeration (Drewry and Paton, 2005).

Besides the attribute type under consideration, it must be considered that the zone relevant for root growth is variable. The study of the surface layer helps to highlight the differences between land use situations (Drewry, 2006), by the logical fact that these layers are immediately influenced by land use change.

The objectives of this study were to investigate the effect of increasing periods of corn crop on various soil attributes, with emphasis on physical attributes, particulate organic matter and total organic $C$, also considering some chemical attributes. The results were compared to those obtained for native vegetation (dry forest) and pastures with a high stocking rate, both in the same landscape and soil condition. Soil quality was used here as defined by Doran et al. (1996), as the capacity of the soil to function within an ecosystem and land-use boundaries to sustain biological productivity, maintain environmental quality, and promote plant and animal health. But, the study was not intended to set limits of the measured parameter values to "ideal/degraded", as performed by Reynolds et al. (2007).

\section{Materials and methods}

\subsection{Area description and soil sampling}

Soil samples were collected in Simão Dias, western Sergipe State, among UTM coordinates $617,824-618,800 \mathrm{mE}$ and $8,809,429-8,811,285 \mathrm{~m} \mathrm{~N}$, in calcareous soils. The climate (Köppen) is a transitional between BSsh' (very hot sub-arid, steppe type and winter rainy season) and the As' (tropical rainy with dry summer and fall rainy season) (Embrapa, 1975; Silva et al., 1993).

Five areas with different conditions of land use, all on flat lands, were selected, with five sites (replicates) for each area. The treatment samples were taken from the same farm. The land use condition of different areas is shown in Table 1. The native vegetation area (dry forest-caatinga transition) corresponds to a small fragment. Native vegetation fragments are very rare in the region and, as usual, in all Brazil sub-arid region.

A soil profile was morphologically described (Santos et al., 2013) and classified (Embrapa, 2013). Soil horizons were sampled, and samples were air-dried, passed through a $2 \mathrm{~mm}$ sieve, and physical, chemical and mineralogical analyses were performed.

For the study of attributes, soil samples were collected at 0 $20 \mathrm{~cm}$ depth in all sites (five treatments with five replicates $=25$ sites). Disturbed soil samples were collected and air-dried (passed through $2 \mathrm{~mm}$ sieve) for solid phase analysis (chemical and physical). Undisturbed samples were also collected using a volumetric ring ( $5.2 \mathrm{~cm}$ diameter and $2.0 \mathrm{~cm}$ height) for physical analyzes, which required soil structure preservation. The sampler was comprised of three stacked rings, taking advantage of the central portion. This ring was placed in the central part of $0-$ $20 \mathrm{~cm}$ depth (between 9 and $11 \mathrm{~cm}$ depth). Soil samples for aggregate analysis were collected from 0 to $20 \mathrm{~cm}$ depth, using a trowel to minimize ped compression.

The sites selection and sampling were carried out in October 2008 , at the end of the crop cycle.

\subsection{Soil analysis}

The following analyzes were performed in $<2 \mathrm{~mm}$ samples for soil genetic horizons and $0-20 \mathrm{~cm}$ depth: particle size distribution by the pipette method (Gee and Bauder, 1986); water pH; organic carbon by Walkley \& Black method (Walkley, 1946); Ca, Mg and Al by $\mathrm{KCl}$ extraction (McLean et al., 1958); K and $\mathrm{Na}$ by $\mathrm{HCl}$ extraction (Mehlich, 1953); H+Al by Ca acetate extraction at pH 7 (Shaw, 1959); P by Mehlich-1 extractant (Mehlich, 1953). The sum of bases, cation exchange capacity, base saturation and Al saturation were calculated. The $\mathrm{pH}$ in $\mathrm{KCl}$ and the calcium carbonate content (Richards et al., 1954) were analysed only in $<2 \mathrm{~mm}$ samples for genetic horizons. For these samples the $\mathrm{pH}$ value at the point of zero charge (PZC) were also estimated as follows: $\mathrm{PZC}=(2 \times \mathrm{KCl}$ pH)-water pH (Zelazny et al., 1996).

The clay fraction was separeted from selected $<2 \mathrm{~mm}$ samples for soil genetic horizons by wet sieving and sedimentation, after dispersion with $\mathrm{NaOH} 1.0 \mathrm{~mol} \mathrm{~L}^{-1}$. Clay mineralogy was determined by X-ray diffraction of oriented slides.

Other soil attributes were performed only from samples 0 $20 \mathrm{~cm}$ depth. Some properties more precisely in 9-11 cm depth were determined from the volumetric rings: bulk density (Archer and Smith, 1972), water retention curve at $-6,-33$ and $-1500 \mathrm{kPa}$ (Haise et al., 1955), and penetration resistance (PR). The PR was determined through a penetrograph apparatus, using undisturbed samples with moisture corresponding to $-6,-33$, and $-1500 \mathrm{kPa}$ (PR6, PR33, and PR1500, respectively). The penetrograph used was a Marconi, MA-933 model, load cell with conic rod ( $4 \mathrm{~mm}$ diameter and $45^{\circ}$ angle), at constant penetration speed of $10 \mathrm{~mm} / \mathrm{min}$, having each test a duration of $80 \mathrm{~s}$. The PR of each test considered the average penetration force data between 40 and $80 \mathrm{~s}$, and the apparatus recorded the data penetration force $(\mathrm{kgf})$ per second.

Table 1

Codes and land use situation for the area groups, all in calcareous soils, Simão Dias, Brazil.

\begin{tabular}{ll}
\hline Code & Land use situation \\
\hline DF & Small fragment of secondary forest, dry forest-arboreous caatinga transition \\
C1 & First year of corn cultivation, after the secondary forest removal \\
C4 & Fourth year of corn cultivation, after the secondary forest removal \\
C10 & Tenth year of corn cultivation, after the secondary forest removal \\
IP & Pangola grass pasture under intensive cattle treading \\
\hline
\end{tabular}




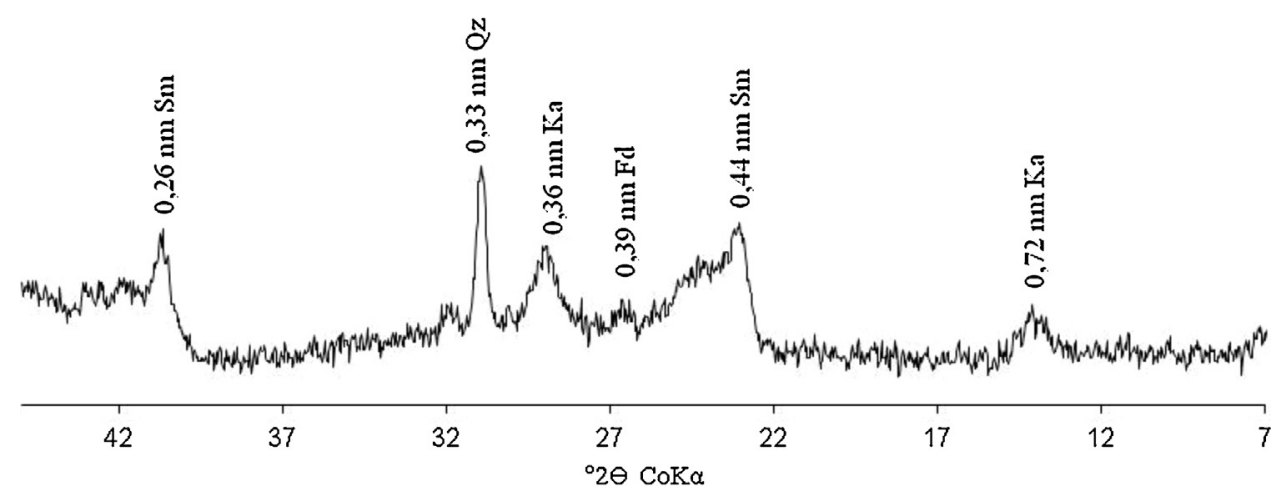

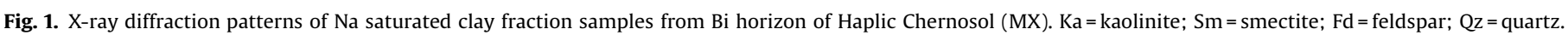
Numbers represent $d$ spacing in $\mathrm{nm}$.

After the test, the samples were oven-dried at $105^{\circ} \mathrm{C}$ for $24 \mathrm{~h}$ to determine the moisture content. These same data were used to determine bulk density and the water retention curve. The total porosity was obtained by the volumetric moisture of the saturated sample. The microporosity was considered in the volumetric moisture of the sample stabilized at $-6 \mathrm{kPa}$ tension. The macroporosity was obtained by the difference between total porosity and microporosity. The field capacity was considered as the equilibrium volumetric water content at $-33 \mathrm{kPa}$ tension and the permanent wilting point was considered as the equilibrium volumetric water content at $-1500 \mathrm{kPa}$ tension. After the wet sieving procedure of the soil samples with minimizing peds compression in the Yoder apparatus, the wet aggregate stability (Kemper and Rosenau, 1986) was calculated by the ratio between the dry aggregate mass at $0.25 \mathrm{~mm}$ sieve and the total mass of dry soil used in the analysis. The average diameter of aggregates stable in water was calculated. The sand fraction $C$ content of the samples was used as an index of particulate organic matter (Amelung et al., 1998).

\subsection{Statistical analyzes of the soil attributes from 0 to $20 \mathrm{~cm}$ depth}

Initially, the generated information was stored into a sites matrix (25) versus soil variables.

The soil chemical and physical attributes at $0-20 \mathrm{~cm}$ depth (including samples $9-11 \mathrm{~cm}$ depth) were analyzed by one-way analysis of variance using the general linear procedure (StatSoft, 2010). Significant differences between averages were assessed by Duncan's test at the 5\% level of significance. The treatments effect (land use-Table 1) was compared using 20 attribute averages.
The data were also analyzed by multivariate analyses. Prior to analysis, the data were normalized by totals within each variable to account for the differences in the variable units.

For each data comparison (land use and increasing periods of corn cultivation) contrasts were performed using the multiresponse permutation procedure (Mielke et al., 1976).

The data of all treatments were analyzed using multivariate ordination non-metric multidimensional scaling (McCune and Grace, 2002) with Sorensen distances. Ordination was performed using the PC-ORD v. 6.0 program (McCune and Mefford, 2011) in autopilot mode with the "slow and thorough" option selected. The number of dimensions to be interpreted was chosen according to the stress and stability of the graphical solutions. The variations between sites were also characterized by calculating Pearson correlation coefficients between the individual values of the variables considered in this study and the non-metric multidimensional scaling scores (axes 1 and 2).

The sum of silt and clay content were not included at the data matrix used for the contrasts using the multi-response permutation procedure (MRPP) and the ordination analysis by non-metric multidimensional scaling (NMS), considering that they are little influenced by land use changes. However, these variables were used to support the interpretation of the variations occurred among the five sampled in the NMS.

\section{Results and discussion}

\subsection{Soil characterization}

The study areas are dominated by soils with vertic properties (wide cracks), as a consequence of the presence of high activity

Table 2

General data of the representative soils for the three land use situations (forest, corn and pasture) in the area groups.

\begin{tabular}{|c|c|c|c|}
\hline & Dry forest (DF) & $\begin{array}{l}\text { Corn areas } \\
(\mathrm{C} 1, \mathrm{C} 4 \text { and } \mathrm{C} 10)\end{array}$ & Intensive pasture (IP) \\
\hline Soil classification (dominant) & \multicolumn{2}{|l|}{ Haplic Chernosol Ortic vertic, leptic, solodic } & CX Carbonatic leptic, vertic \\
\hline Parent material & \multicolumn{2}{|l|}{ Reworking of the local limestone } & \\
\hline Surface horizon type & \multicolumn{2}{|l|}{ Mollic epipedon } & Ochric epipedon \\
\hline Situation & \multicolumn{2}{|l|}{ Flat summit, with some concave areas } & \\
\hline Primary vegetation & \multicolumn{2}{|l|}{ Dry forest (transition to arboreal caatinga) } & \\
\hline Drainage & \multicolumn{2}{|l|}{ Moderately to imperfectly drained } & \\
\hline Rock fragments in the soil & Less than $15 \%$ & Not present & \\
\hline Soil deep & $>82 \mathrm{~cm}$, there may be more shallow soils & $>82 \mathrm{~cm}$ & \\
\hline Particle size distribution of A horizon & \multicolumn{2}{|l|}{ loam to clay } & loam \\
\hline Particle size distribution of $\mathrm{B}$ horizon & \multicolumn{2}{|l|}{ loam to clay } & \\
\hline Soil color of A horizon & \multicolumn{2}{|c|}{ black (10YR 2/1) with very dark brown (10YR $2 / 2$ ) mottles } & very dark grayish brown (10YR 3/2) \\
\hline Soil color of B horizon & \multicolumn{2}{|l|}{ dark yellowish brown (10YR 4/4 and 10YR 4/5) } & \\
\hline Effervescence in cold dilute $\mathrm{HCl}$ & \multicolumn{2}{|l|}{ presence } & \\
\hline
\end{tabular}


Table 3

Some physical and chemical characteristics of a Haplic Chernosol (MX) profile, dominant soil of study areas.

\begin{tabular}{|c|c|c|c|c|c|}
\hline \multirow[t]{2}{*}{ Characteristic } & \multirow[t]{2}{*}{ Unit } & \multicolumn{4}{|c|}{ Horizons } \\
\hline & & Ap & $\mathrm{AB}$ & $\mathrm{Bi}$ & $\mathrm{BC}$ \\
\hline Upper limit & $\mathrm{cm}$ & 0 & 17 & 27 & 64 \\
\hline Lower limit & $\mathrm{cm}$ & 17 & 27 & 64 & 82 \\
\hline Sand & $\mathrm{g} 100 \mathrm{~g}^{-1}$ & 17 & 8 & 10 & 10 \\
\hline Silt & $\mathrm{g} 100 \mathrm{~g}^{-1}$ & 37 & 41 & 48 & 50 \\
\hline Clay & $\mathrm{g} 100 \mathrm{~g}^{-1}$ & 46 & 51 & 42 & 40 \\
\hline Water $\mathrm{pH}$ & - & 6.3 & 6.4 & 7.5 & 8.1 \\
\hline $\mathrm{KCl} \mathrm{pH}$ & - & 5.4 & 5.3 & 5.5 & 5.9 \\
\hline Point of zero charge & - & 4.5 & 4.2 & 3.5 & 3.7 \\
\hline Organic C & $\mathrm{g} \mathrm{kg}^{-1}$ & 13.9 & 3.50 & 0.60 & 0.01 \\
\hline $\mathrm{P}$ & $\mathrm{mg} \mathrm{kg}^{-1}$ & 3.7 & 1.4 & 0.9 & 0.6 \\
\hline $\mathrm{Ca}$ & $\mathrm{c} \mathrm{mol}_{\mathrm{c}} \mathrm{kg}^{-1}$ & 7.2 & 6.9 & 20.0 & 16.0 \\
\hline Mg & $\mathrm{c} \mathrm{mol}_{\mathrm{C}} \mathrm{kg}^{-1}$ & 4.8 & 3.5 & 2.0 & 1.6 \\
\hline $\mathrm{Na}$ & $\mathrm{cmol}_{\mathrm{c}} \mathrm{kg}^{-1}$ & 0.25 & 0.55 & 0.87 & 2.23 \\
\hline K & $\mathrm{cmol}_{\mathrm{C}} \mathrm{kg}^{-1}$ & 0.20 & 0.08 & 0.06 & 0.05 \\
\hline $\mathrm{Al}$ & $\mathrm{cmol}_{\mathrm{C}} \mathrm{kg}^{-1}$ & 0.1 & 0.1 & 0.0 & 0.0 \\
\hline $\mathrm{H}+\mathrm{Al}$ & cmolc kg $^{-1}$ & 3.6 & 2.6 & 1.3 & 1.1 \\
\hline Sum of bases & $\mathrm{cmol}_{\mathrm{c}} \mathrm{kg}^{-1}$ & 12.45 & 11.03 & 22.93 & 19.88 \\
\hline Cation exchange capacity & $\mathrm{cmol}_{\mathrm{C}} \mathrm{kg}^{-1}$ & 16.05 & 13.63 & 24.23 & 20.98 \\
\hline Bases saturation & $\%$ & 78 & 81 & 95 & 95 \\
\hline Al saturation & $\%$ & 1 & 1 & 0 & 0 \\
\hline Na saturation & $\%$ & 2 & 4 & 4 & 11 \\
\hline $\mathrm{CaCO}_{3}$ & $\mathrm{~g} \mathrm{~kg}^{-1}$ & 63.31 & 63.08 & 62.56 & 56.33 \\
\hline
\end{tabular}

clays (smectitic group) (Fig. 1). All areas (Table 1) have soils with a mollic epipedon or with a mollic epipedon that was truncated by erosion (an ochric epipedon). In the last case, in the IP area, human activities may have altered the surface horizon, changing a mollic epipedon into an ochric epipedon. Therefore, the soils are classified as Haplic Chernosol in DF and corn areas and as Haplic Cambisol in the IP area. There may be the inclusion of Litolic Neosol (intergrade to Chernosol) in the forest area, as a result of the shallower soil of this area compared to the areas of corn crop and pasture (Table 2). Thus, the soils can be considered moderately deep, with rock presence below $82 \mathrm{~cm}$ depth. In the DF sites, the soils are a little shallower, with rock depth occurring from about $50 \mathrm{~cm}$.

The forest soils are clayey to loamy in the surface, as a consequence of limestone parent material, having a low quartz content in its mineralogical constitution. The cultivated soil for different reasons, has a somewhat coarser texture. In corn sites soil tillage mixed layers of different depths and in IP sites differential soil erosion has increased the sand fraction.

Some areas have concave relief, which makes drainage worse, whithout influencing the topsoil. This concave relief helps to explain the increase of $\mathrm{Na}$ saturation at depth (Table 3). The exchange complex of the soil profile has a high base saturation. The soil $\mathrm{pH}$ is slightly acid in the topsoil and slightly basic on the subsurface. The profile has hypocarbonate character (Embrapa, 2013), which is given by $\mathrm{CaCO}_{3}$ contents between 50 and $150 \mathrm{~g} \mathrm{~kg}^{-1}$ in all parts of the soil control section (Table 3). The differences between the soil water $\mathrm{pH}$ and the soil $\mathrm{KCl} \mathrm{pH}$ and the PZC calculated values at all horizons show an overall predominance of soil net negative charges.

\subsection{Soil attribute behavior considering land use}

Even with the local flat relief, the IP sites showed strong sheet erosion. The pasture sites had a strong depletion of silt+clay fractions compared to other land uses (forest-DF and corn-C1, C4 and C10) (Table 4). The inadequate management (intensive grazing beyond the supported capacity) altered the surface particle size distribution of the IP sites, which is an attribute commonly very little affected by land use.

Moreover, almost all the chemical and physical attributes showed a lesser quality in IP sites compared to other treatments. The differences among the DF sites and corn crop sites (C1, C4 and C10) were less. The bulk density, macroporosity and total porosity were the only variables that were isolated to the DF sites compared to the corn treatments (Table 4 and Fig. 2), remembering that these three attributes are part of those sampled from 9 to $11 \mathrm{~cm}$ depth.

All contrasts made between the three land use groups by multiresponse permutation procedure technique were significant (Table 5). Compaction by cattle treading happens more consistently at the $0-20 \mathrm{~cm}$ depth (Drewry and Paton, 2000), and here the sites subjected to intense grazing usually showed, compared to sites without such land use, greater bulk density and penetration resistance values (Silva et al., 2003; Franzluebbers and Stuedemann,

Table 4

Soil attributes average values $(n=5)$ of area groups, $0-20 \mathrm{~cm}$.

\begin{tabular}{|c|c|c|c|c|c|c|}
\hline \multirow[t]{2}{*}{ Attribute } & \multirow[t]{2}{*}{ Unit } & \multicolumn{5}{|c|}{ Treatment } \\
\hline & & DF & $\mathrm{C} 1$ & $\mathrm{C} 4$ & $\mathrm{C} 10$ & IP \\
\hline Silt + clay & $\mathrm{g} 100 \mathrm{~g}^{-1}$ & $74 b$ & $75 b$ & $71 b$ & $75 b$ & $52 a$ \\
\hline Bulk density $^{a}$ & $\mathrm{~g} \mathrm{~cm}^{-3}$ & $1.31 \mathrm{a}$ & $1.58 \mathrm{~b}$ & $1.52 \mathrm{~b}$ & $1.57 \mathrm{~b}$ & $1.74 \mathrm{c}$ \\
\hline Macroporosity $^{\mathrm{a}}$ & $\mathrm{m}^{3} \mathrm{~m}^{-3}$ & $0.22 \mathrm{c}$ & $0.14 b c$ & $0.12 \mathrm{ab}$ & $0.12 \mathrm{ab}$ & $0.05 a$ \\
\hline Microporosity $^{\mathrm{a}}$ & $\mathrm{m}^{3} \mathrm{~m}^{-3}$ & $0.31 \mathrm{abc}$ & $0.30 \mathrm{ab}$ & $0.32 \mathrm{bc}$ & $0.34 \mathrm{c}$ & $0.28 \mathrm{a}$ \\
\hline Total porosity ${ }^{\mathrm{a}}$ & $\mathrm{m}^{3} \mathrm{~m}^{-3}$ & $0.53 c$ & $0.43 b$ & $0.44 b$ & $0.46 b$ & $0.33 a$ \\
\hline Field capacity $(-33 \mathrm{kPa})^{\mathrm{a}}$ & $\mathrm{m}^{3} \mathrm{~m}^{-3}$ & $0.27 b$ & $0.26 b$ & $0.28 \mathrm{~b}$ & $0.29 b$ & $0.2 \mathrm{a}$ \\
\hline Permanent wilting point $(-1500 \mathrm{kPa})^{\mathrm{a}}$ & $\mathrm{m}^{3} \mathrm{~m}^{-3}$ & $0.22 \mathrm{bc}$ & $0.20 \mathrm{~b}$ & $0.24 \mathrm{c}$ & $0.27 d$ & $0.16 \mathrm{a}$ \\
\hline Aggregates average diameter & $\mathrm{mm}$ & $2.31 \mathrm{~d}$ & $2.21 \mathrm{~cd}$ & $1.58 \mathrm{~b}$ & $1.2 \mathrm{a}$ & $1.85 \mathrm{bc}$ \\
\hline Wet aggregates stability & $\%$ & $93 b$ & $92 b$ & $81 a$ & $76 a$ & $81 a$ \\
\hline PR6 $^{\mathrm{a}}$ & $\mathrm{kPa}$ & $709 b$ & $270 a$ & $744 \mathrm{~b}$ & $689 b$ & $1447 \mathrm{c}$ \\
\hline $\mathrm{PR} 33^{\mathrm{a}}$ & $\mathrm{kPa}$ & $1227 b$ & $558 a$ & $1220 b$ & 1147b & $2184 c$ \\
\hline PR1500 & $\mathrm{kPa}$ & $1766 a$ & $1616 a$ & $1928 a$ & $1752 a$ & $4524 b$ \\
\hline $\mathrm{pH}$ & - & $6.0 \mathrm{a}$ & $6.6 \mathrm{ab}$ & $7.7 \mathrm{c}$ & $7.2 \mathrm{bc}$ & $7.2 \mathrm{bc}$ \\
\hline Organic C & $\mathrm{g} \mathrm{kg}^{-1}$ & $21.69 c$ & $21.4 \mathrm{c}$ & $15.17 \mathrm{~b}$ & $16.65 b$ & $7.43 a$ \\
\hline Particulate organic matter & $\mathrm{g} \mathrm{kg}^{-1}$ & $8.0 \mathrm{~b}$ & $8.77 b$ & $2.98 \mathrm{a}$ & $3.57 a$ & $2.96 a$ \\
\hline $\mathrm{P}$ & $\mathrm{mg} \mathrm{kg}^{-1}$ & $3.3 a$ & $6.1 b$ & $3.5 a$ & $4.1 \mathrm{a}$ & $3.2 \mathrm{a}$ \\
\hline $\mathrm{H}+\mathrm{Al}$ & $\mathrm{cmol}_{\mathrm{c}} \mathrm{kg}^{-1}$ & $2.28 \mathrm{~b}$ & $1.53 \mathrm{ab}$ & $0.53 a$ & $1.32 \mathrm{ab}$ & $0.68 \mathrm{a}$ \\
\hline Sum of bases & $\mathrm{cmol}_{\mathrm{c}} \mathrm{kg}^{-1}$ & $23.29 b$ & $25.26 \mathrm{~b}$ & $21.76 b$ & $20.5 b$ & $9.7 a$ \\
\hline Cation exchange capacity & $\mathrm{cmol}_{\mathrm{c}} \mathrm{kg}^{-1}$ & $25.57 b c$ & $26.79 c$ & $22.29 b c$ & $21.82 b$ & $10.38 \mathrm{a}$ \\
\hline Bases saturation & $\%$ & $91 \mathrm{a}$ & $94 \mathrm{ab}$ & $98 b$ & 94ab & $93 a b$ \\
\hline
\end{tabular}

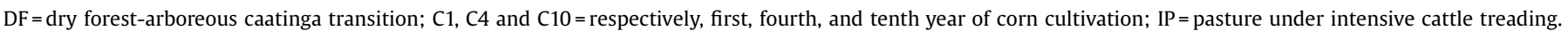
PR6, PR33 and PR1500: respectively, soil penetration resistance at $-6,-33$, and $-1500 \mathrm{kPa}$ matric potentials.

Means in the same row followed by the same letter were not significantly different by Duncan's test $(p<0.05)$.

a Samples from 9 to $11 \mathrm{~cm}$ depth. 

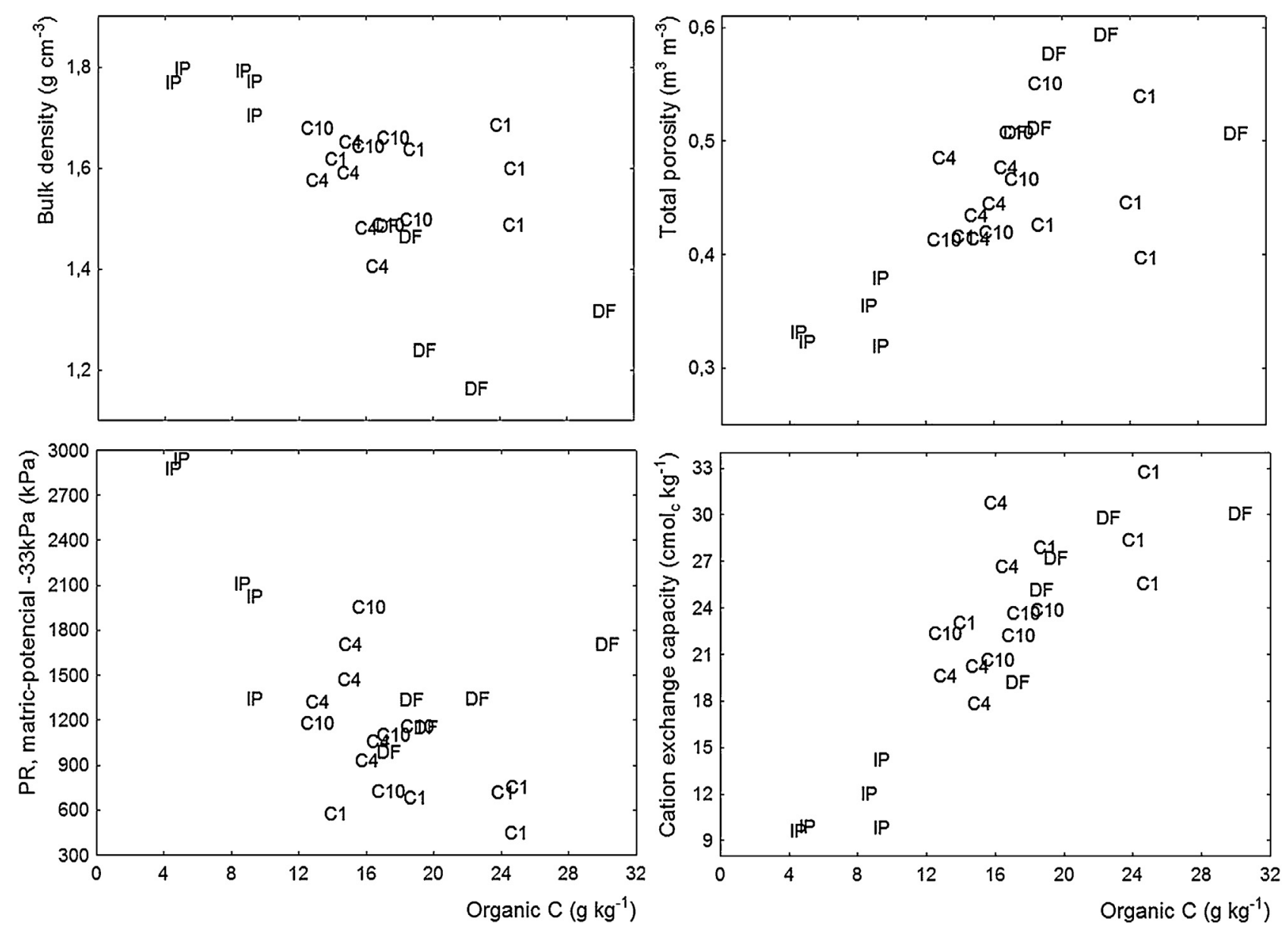

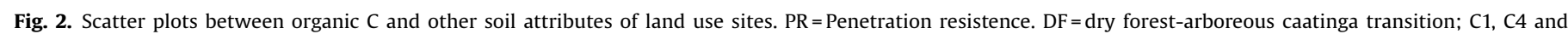
$\mathrm{C} 10=$ respectively, first, fourth, and tenth year of corn cultivation after the secundary forest removal; IP = pasture under intensive cattle treading.

2008). In this case, the high animal treading effects (Drewry and Paton, 2005) exceeds the machinery traffic effects in the corn crop treatments ( $\mathrm{C} 1, \mathrm{C} 4$ and $\mathrm{C} 10)$. In general, the latter is considered the main cause of compaction of agricultural soils (Hammad and Dawelbeit, 2001; Silva et al., 2009; Machado et al., 2010).

\subsection{Soil attributes behavior considering land use time of corn crop}

The differences between the variable comparisons are diffuse. Some attributes showed no significant differences (sum of bases, silt + clay, field capacity and PR1500). The bulk density and total porosity were the only attributes that completely separated the forest (time zero) from corn treatments.

Tenuously, some attributes formed two groups, where DF and C1 treatments were separated from C4 and C10 treatments. This was most noticeable in aggregate average diameter, wet aggregate stability, organic C, and particulate organic matter attributes (Table 4 and Fig. 3 ).

For the corn crop treatments, only one contrast showed no significant difference by the multi-response permutation procedure technique. It was performed between C4 and C10 groups (Table 5). Thus, the approximation between the DF and C1 groups, noticeable for some attributes, was weakened by the set of all

Table 5

Soil quality contrasts, described by the combined analysis of nineteen attributes. The groups were defined by land use and land use time of corn crop.

\begin{tabular}{ll}
\hline Contrast & $P$ value \\
\hline Land use & $0.009^{* *}$ \\
Dry forest versus corn crop & $0.002^{* *}$ \\
Dry forest versus pasture under intensive cattle treading & $0.00001^{* * *}$ \\
Corn crop versus pasture under intensive cattle treading & $0.02^{*}$ \\
& $0.006^{* *}$ \\
Land use time of corn crop & $0.007^{* *}$ \\
Forest (zero time) versus first year of corn cultivation & $0.007^{* *}$ \\
Forest (zero time) versus fourth year of corn cultivation & $0.01^{*}$ \\
First year of corn cultivation versus fourth year of corn cultivation & $0.5^{\mathrm{ns}}$ \\
First year of corn cultivation versus tenth year of corn cultivation & \\
Fourth year of corn cultivation versus tenth year of corn cultivation & \\
\hline
\end{tabular}

Significance: ns-non significant; ${ }^{*} p<0.05 ;{ }^{* *} p<0.01 ;{ }^{* * *} p<0.001$. 

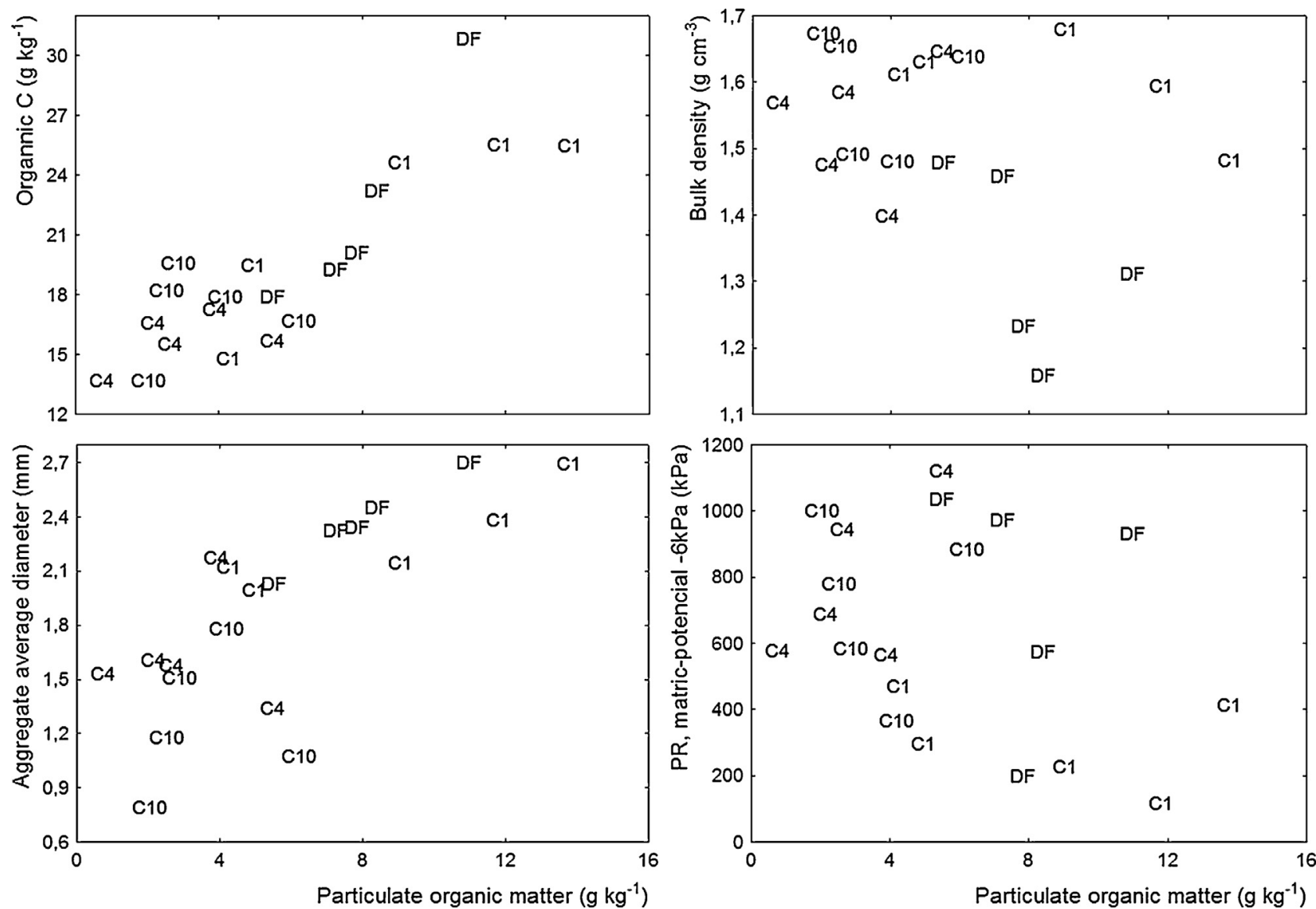

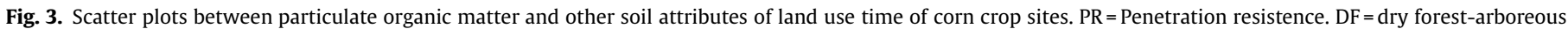
caatinga transition, as a zero time; $\mathrm{C} 1, \mathrm{C} 4$ and $\mathrm{C} 10$ = respectively, first, fourth, and tenth year of corn cultivation after the secundary forest removal.

attributes. Overall, the results were similar to those found by Chaer et al. (2009) and Sant'anna et al. (2009), showing the deleterious effects of repeated revolving operations on several soil properties (organic carbon, bulk density, aggregate average diameter, wet aggregate stability, etc.). However, these effects did not extend beyond a certain number of cultivation cycles (between four and ten years). This buffering of deleterious effects may be a consequence of the good structural condition of the Chernosol topsoil (Miller and Donahue, 1990). In addition, the local climate allows only one crop cultivation per year, followed by a "fallow" period forced by the strong water deficit (7-8 months per year). These two aspects helps the soil functions to return, at least

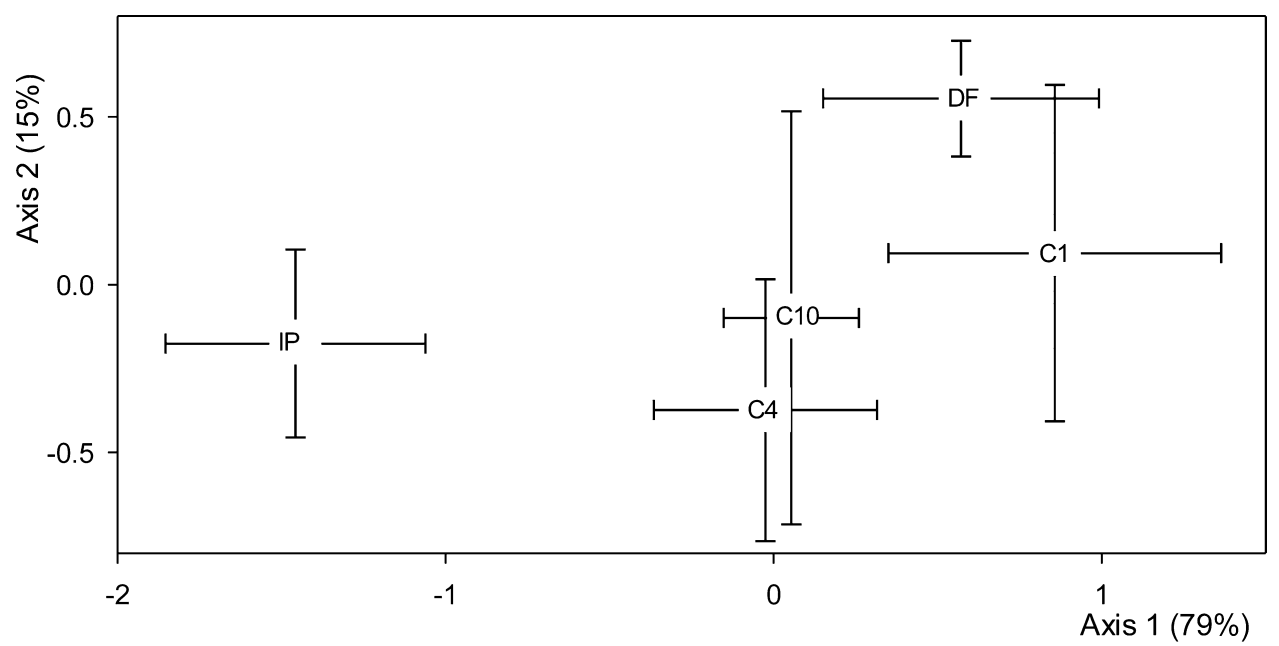

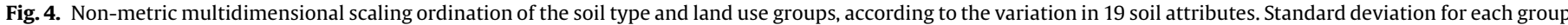

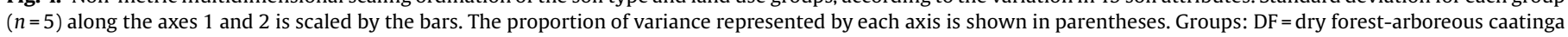

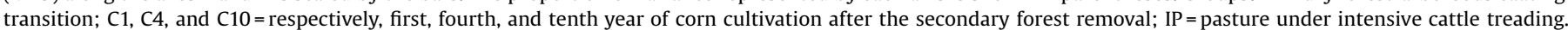


Table 6

Pearson correlation coefficients between soil variables and scores along non-metric multidimensional scaling axes 1 and 2 (Fig. 4)

\begin{tabular}{lll}
\hline Attribute & Axis 1 & Axis 2 \\
\hline pH & -0.30 & $-0.91^{* * *}$ \\
Organic C & $0.94^{* * *}$ & 0.33 \\
Particulate organic matter & $0.69^{* *}$ & $0.44^{*}$ \\
$\mathrm{P}$ & $0.50^{*}$ & -0.35 \\
$\mathrm{H}+\mathrm{Al}$ & 0.35 & $0.94^{* * *}$ \\
Sum of bases & $0.93^{* * *}$ & 0.04 \\
Cation exchange capacity & $0.95^{* * *}$ & 0.17 \\
Bases saturation & 0.12 & $-0.84^{* * *}$ \\
Silt + clay & $0.77^{* * *}$ & 0.37 \\
Bulk density & $-0.68^{* *}$ & $-0.56^{* *}$ \\
Macroporosity & $0.64^{* *}$ & $0.65^{* *}$ \\
Microporosity & 0.26 & -0.32 \\
Total porosity & $0.74^{* * *}$ & $0.53^{*}$ \\
Field capacity & $0.66^{* *}$ & -0.04 \\
Permanent wilting point & $0.50^{*}$ & -0.02 \\
Aggregates average diameter & 0.40 & $0.58^{* *}$ \\
Wet aggregate stability & $0.57^{* *}$ & $0.60^{* *}$ \\
Soil penetration resistance at $-6 \mathrm{kPa}$ matric-potential & $-0.86^{* * *}$ & -0.20 \\
Soil penetration resistance at $-33 \mathrm{kPa}$ matric-potential & $-0.80^{* * *}$ & -0.12 \\
Soil penetration resistance at $-1500 \mathrm{kPa}$ matric-potential & $-0.80^{* * *}$ & -0.19 \\
\hline Significance: ns-non significant; ${ }^{*} p<0.05 ;{ }^{* *} p<0.01 ;{ }^{* * *} p<0.001$. & \\
a The Silt + clay attribute was not included in the non-metric multidimensional \\
analysis. & & \\
\hline
\end{tabular}

partially, toward their initial condition. The buffering of soil physical conditions has a limit, which was not achieved by the time sequence of corn crop tested (ten years).

The local climate leaves a short time interval for the corn crop cycle. Thus, it is fair to consider that much of the soil physical properties deterioration presented in C4 and C10 treatments, when they were compared to DF and C1 treatments, are coming from the intensive machinery traffic (especially from soil preparation for planting) under soil excessive moisture conditions (Severiano et al., 2008; Ng Cheong et al., 2009).

\subsection{Comparison of all treatments}

The two-dimensional non-metric multidimensional scaling technique explained $94 \%$ of the variability of the 19 attributes analyzed, being the major part represented by axis 1 (79\%) and only $15 \%$ by axis 2 (Fig. 4 and Table 6 ). The site distribution on axis 1 was positively correlated $(p<0.05-p<0.001)$ with organic carbon, particulate organic matter, $P$, sum of bases, cation exchange capacity, silt + clay, macroporosity, total porosity, field capacity, permanent wilting point, and wet aggregate stability, and negatively correlated $(p<0.01-p<0.001)$ with bulk density, PR6, PR33, and PR1500. By the groups position in the two-dimensional non-metric multidimensional scaling technique, the correlations between the attributes of axis 1 and the contrasts between groups (Table 5), it is apparent that soil quality of different sites increased from left to right of axis 1 . A decreasing environmental gradient was formed between the groups in the following order: $\mathrm{C} 1>\mathrm{DF}>$ $(C 4=C 10)>$ IP. The C4 and C10 groups were highly overlapping by the non-metric multidimensional scaling and the contrast by the multi-response permutation procedure was not significant. DF and C1 groups showed little difference by the non-metric multidimensional scaling, although the contrast between the two groups was significant $(P<0.05)$.

The $\mathrm{C} 1$ sites were positioned slightly to the right of the DF sites in the axis 1 by the non-metric multidimensional scaling. This position was greatly influenced by the penetration resistence lower values of C1 sites, PR6 and PR33 atributtes (Table 4). The penetration resistence had lower values at C1 sites compared with DF sites, what it was probably caused by a positive and temporary effect of the soil preparation in $\mathrm{C} 1$ sites. The $\mathrm{C} 1$ sites have only one crop cycle after secondary forest removal, and there were no significant differences in organic carbon average values between the two conditions (Table 4). This positive effect of soil preparation disappears when the number of cultivation years increases. Along non-metric multidimensional scaling axis 2, the set of C4 and C10 sites are closer to the C1 group than the DF group, and the variable that most contributes to this is the bulk density.

\section{Conclusion}

The pasture sites with high stocking rate had the greatest soil degradation index of physical conditions among all groups.

The one year corn crop cultivation after the secondary forest removal sites had significant contrast compared to the forest. However, considering the behavior of the different variables and the position reached in the non-metric multidimensional scaling, it can be considered as an adequate soil quality condition.

Compared to the one year corn cultivation, the four years cultivation have caused the quality loss of various physical soil properties quality in Chernosols.

There were no differences between four and ten years corn cultivation after the secondary forest removal. This indicated that a near steady state was achieved and it may require a greater number of cultivation years to be exceeded before a threshold is obtained and quality reduces further.

\section{Acknowledgment}

To FAPITEC/SE, for financing the research actions of this project, and to $\mathrm{CNPq}$ and FAPEMIG.

\section{References}

Amelung, W., Zech, W., Flach, K.W., 1998. Carbon, nitrogen and sulfur pools in particle-size fractions as influenced by climate. Soil Sci. Soc. Am. J. 62, 172-181.

Archer, J.R., Smith, P.D., 1972. The relation between bulk density, available water capacity, and air capacity of soils. J. Soil Sci. 23, 475-480.

Bronick, C.J., Lal, R., 2005. Soil structure and manegement: a review. Geoderma 124, $3-22$.

Chaer, G.M., Fernandes, M.F., Myrold, D.D., Bottomley, P.J., 2009. Shifts in microbial community composition and physiological profi les across a gradient of induced soil degradation. Soil Sci. Soc. Am. J. 73, 1327-1334.

Doran, J.W., Sarrantonio, M., Lieberg, M.A., 1996. Soil health and sustainability. Adv. Agron. 56, 1-54.

Drewry, J.J., Paton, R.J., 2000. Effects of cattle treading and natural amelioration on soil physical properties and pasture under dairy farming in Southland, New Zealand. N. Z. J. Agric. Res. 43, 377-386.

Drewry, J.J., Paton, R.J., 2005. Soil physical quality under cattle grazing of a winterfed brassica crop. Aust. J. Soil Res. 43, 525-531.

Drewry, J.J., 2006. Natural recovery of soil physical properties from treading damage of pastoral soils in New Zealand and Australia: a review. Agric. Ecosyst. Environ. $114,159-169$.

Embrapa, 1975. Levantamento exploratório-reconhecimento de solos do Estado de Sergipe. EMBRAPA/SUDENE. Boletim Técnico 36, Recife, Brazil 506p.

Embrapa, 1977. Levantamento exploratório reconhecimento de solos da margem direita do Rio São Francisco Estado da Bahia, vol. I. EMBRAPA, Boletim Técnico 52, Recife, Brazil 738p.

Embrapa, 2013. Sistema brasileiro de classificação de solos, 3rd ed. Embrapa, Brasília 353p.

Franzluebbers, A.J., Stuedemann, J.A., 2008. Soil physical responses to cattle grazing cover crops under conventional and no tillage in the Southern Pedmont USA. Soil Till. Res. 100, 141-153.

Gee, G.W., Bauder, J.W., 1986. Particle-size analysis, In: Klute, A. (Ed.), Methods of Soil Analysis, Part 1. 2nd ed. American Society of Agronomy, Madison, pp. 383-411.

Haise, H.R., Haas, H.J., Jensen, L.R., 1955. Soil moisture studies of some Great Plains soils. II. Field capacity as related to $1 / 3$-atmosphere percentage, and minimum point as related to 15 - and 26-atmosphere percentage. Soil Sci. Soc. Am. Proc. 19 20-25.

Hammad, E.A., Dawelbeit, M.I., 2001. Effect of tillage and field condition on soil physical properties, cane and sugaryields in Vertisols of Kenana Sugar Estate, Sudan. Soil Till. Res. 62, 101-109. 
Hamza, M.A., Anderson, W.K., 2005. Soil compaction in cropping sytems. A review of the nature, causes and possible solutions. Soil Till. Res. 82, 121-145.

Kemper, W.D., Rosenau, R.C., 1986. Aggregate stability and size distribution, In: Klute, A. (Ed.), Methods of Soil Analysis, Part 1. 2nd ed. American Society of Agronomy, Madison, pp. 837-871.

Machado, W., Telles, T.S., Tavares, F.J., Guimarães, de, M.F., Alves, G.B., Borges, J.L.B. 2010. Physical properties of a Rhodic Haplustox under two sugarcane harvesting sytems. R. Bras. Ci. Solo 34, 1803-1809.

McCune, B., Grace, J.B., 2002. Analysis of Ecological Communities. MjM Software Design, Gleneden Beach.

McCune, B., Mefford, M.J., 2011. PC-ORD, Multivariate Analysis of Ecological Data, Version 6.04. Gleneden Beach, MjM Software Design.

McLean, E.O., Hedleson, M.R., Bartlett, R.J., Holowaychuk, D.R., 1958. Aluminium in soils: I. Extraction methods and magnitude clays in Ohio soils. Soil Sci. Soc. Am. Proc. 22, 382-387.

Mehlich, A., 1953. Determination of P, Ca, Mg, K, Na and $\mathrm{NH}_{4}$. North Carolina Soil Testing Division, Raleigh 195p.

Mielke, P.W., Berry, K.J., Johnson, E.S., 1976. Multiresponse permutation procedures for a priori classifications. Commun. in Stat. - Theory and Methods 5, 14091424.

Miller, R.W., Donahue, R.L., 1990. 6th ed.. Soils: An Introduction to Soils and Plant Growth. Prentice Hall, Englewood Cliffs 768p.

Ng Cheong, Ng Kee Kwong, L.R., Ah Koon, K.F., Du, P.D., Preez, C.C., 2009. Changes in Inceptsol of Mauritius after rock removal for sugar cane production. Soil Till. Res. 104, 88-96.

Reynolds, W.D., Drury, C.F., Yang, X.M., Fox, C.A., Tan, C.S., Zhang, T.Q., 2007. Land management effects on the near-surface physical quality of a clay loam soil. Soil Till. Res. 96, 316-330.

Richards et al. 1954. Determination of the properties of saline and alkali soils, in: Richards, L.A. (Ed.). Diagnosis and improvement of saline and alkali soils. USDA Agriculture Handbook 60, United States Department of Agriculture;

Washington, pp. 7-33.
Sant'anna, S.A.C., Fernandes, M.F., Ivo, W.M.P.M., Costa, J.L.S., 2009. Evaluation of soil quality indicators in sugarcane manegement in sandy loam soil. Pedosphere 19, 312-322.

Santos, R.D., Lemos, R.C., Santos, H.G., Ker, J.C., Anjos, L.H.C., Shimizu, S.H., 2013. Manual de descrição e coleta de solo no campo, 6th ed SBCS, Viçosa, pp. 100p.

Severiano, E.C., Dias Júnior, M.S., Oliveira, L.F.C., Castro, M.B., 2008. Pressão de préconsolidação e intervalo hídrico ótimo como indicadores de alterações estruturais de um Latossolo e de um Cambissolo sob cana-de-açúcar. R. Bras. Ci. Solo 32, 1419-1427.

Shaw, W.M., 1959. Determination of exchangeable hydrogen and lime requeriment of soils. J. Assoc. Off. Agric. Chem. 34, 437-452.

Shioga, P.S., Gerage, A.C., Araújo, P.M., Bianco, R., Custódio de, A.A.P., 2013. Avaliação estadual de cultivares de milho, safra 2012/2013. IAPAR Boletim técnico 79, Londrina, pp. 100p.

Shukla, M.K., Lal, R., Ebinger, M., 2006. Determining soil quality indicators by factor analysis. Soil Till. Res. 87, 194-204.

Silva, F.B.R., Riché, G.R., Tonneau, J.P., Souza Neto, N.C., Brito, L.T.L., Correia, R.C., Cavalcanti, A.C., Silva, F.H.B.B., Silva, A.B., Araújo Filho, J.C., Leite, A.P., 1993. Zoneamento agroecológico do Nordeste, diagnóstico do quadro natural e agrossocioeconômico. EMBRAPA CPATSA/CNPS, Petrolina/Recife, Brazil.

Silva, A.P., Imhoff, S., Corsi, M., 2003. Evaluation of soil compactions in an irrigated short-duration grazing system. Soil Till. Res. 70, 83-90.

Silva, R.B., Lanças, K.P., Miranda, E.E.V., Silva, F.A.M., Baio, F.H.R., 2009. Estimation and evaluation of dynamic properties as indicators of changes on soil structure in sugarcane fields of São Paulo State-Brazil. Soil Till. Res 103, 265-270.

StatSoft, 2010. Statistica for windows. Release 5.1 (Computer program manual). StatSoft, Inc., Tulsa.

Walkley, A., 1946. A critical examination of rapid method for determination, organic caron in soils: effects of variations in digestion conditious and organic soils constituents. Soil Sci. 63, 251-263.

Zelazny, L.W., He, L., Vanwormhoudt, A.M., 1996. Charge analysis of soils and anion exchange. In: Bartels, J.M., Bigham, J.M. (Eds.), Methods of Soil Analysis, Part 3, Chemical Methods. American Society of Agronomy, Madison, pp. 1231-1254. 